\title{
人工知能の研究開発に 関する政府の取組
}

\section{新田隆夫 Takao Nitta 内閣府}

\section{はじめに}

内閣府においては，第 5 期科学技術基本計画におい

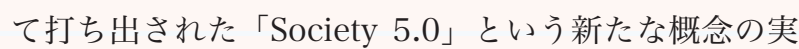
現や，同計画に定められている我が国における官民合わ せた研究開発投資を対 GDP 比の $4 \%$ 以上とするとの目 標の達成に向けて，様々な施策を展開している.

Society 5.0 の実現に向けては, 重要な基盤となる人 工知能 (AI) 関連の研究開発の取組を強化することが 必要である。本稿において, 政府及び内閣府における Society 5.0 の実現と, その鍵となるAI の研究開発に 関する取組について紹介する.

\section{Society 5.0 の実現に向けて}

\subsection{Society 5.0 とは}

Society 5.0 とは, IoT, ロボット, 人工知能 (AI), ビッグデータなどの新たな技術をあらゆる産業や社会生 活に取り入れてイノベーションを創出し，一人一人の ニーズに合わせる形で社会的課題を解決する新たな社会 である(図 1).

この Society 5.0 とは, 人類史の狩編社会を第 1 章 （1.0）とすると，米や小麦で安定した食料を手にした農 耕社会である第 2 章 (2.0), 産業化による大量生産が始 まった工業社会である第 3 章 (3.0), 通信とコンピュー 夕が融合した情報社会である第 4 章 (4.0) に続く, 第 5 番目の新たな社会を指すもので, 人や冈もの囚が皆つ ながり，全ての技術が融合してこれまで解決できなかっ た問題を解けるようになる人類史の第 5 章，新たな社 会の開幕の意味を込めている.

Society 5.0 のポイントは, (1)サイバー空間とフイジ カル空間の高度な融合（図 2), (2)経済的発展と社会的 課題の解決の両立，(3)人間中心の社会である.

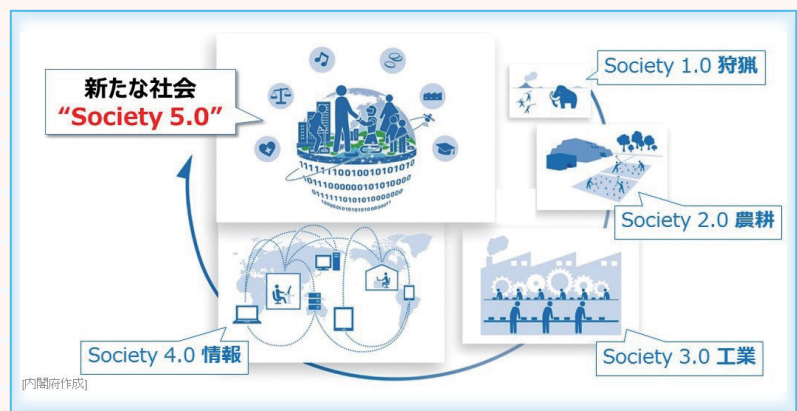

図 1 Society 5.0 とは

これまでの情報社会では，人がサイバー空間に存在す るクラウドサービス（データベース）にインターネット を経由してアクセスして, 情報やデータを検索して入手 し, 分析を行ってきた. Society 5.0 の新たな社会では, フィジカル空間において張り巡らされたセンサなどから IoT を通じて, 環境情報, 機器の作動情報，人の情報な どのあらゆるデータがサイバー空間に収集され，フィジ カル空間の膨大なデータがビッグデータとして集積さ れ，サイバー空間において，この膨大なビッグデータを 人間の能力を超えた $\mathrm{AI}$ が解析し，その解析結果が高付 加価値な情報, 提案, 機器へ指示されることによって, ロボットや自動走行車などのアクチュエータなどを通じ てフィジカル空間の人間に作用（フィードバック）され ることにより, 新たな価值が創出される。すなおち, $\mathrm{AI}$ は，Society 5.0 実現の鍵となる基盤技術として位置 付けられる。

\section{2 第 5 期科学技術基本計画}

科学技術基本計画は，科学技術基本法に基づき政府が 策定する， 10 年先を見通した 5 年間の科学技術の振興 に関する総合的な計画をとりまとめた閣議決定文書であ る（図 3)。また，第 5 期科学技術基本計画は，2016 年度から 2020 年度の 5 年間における我が国の科学技術 イノベーション政策に関する基本計画であり, 総合科学 


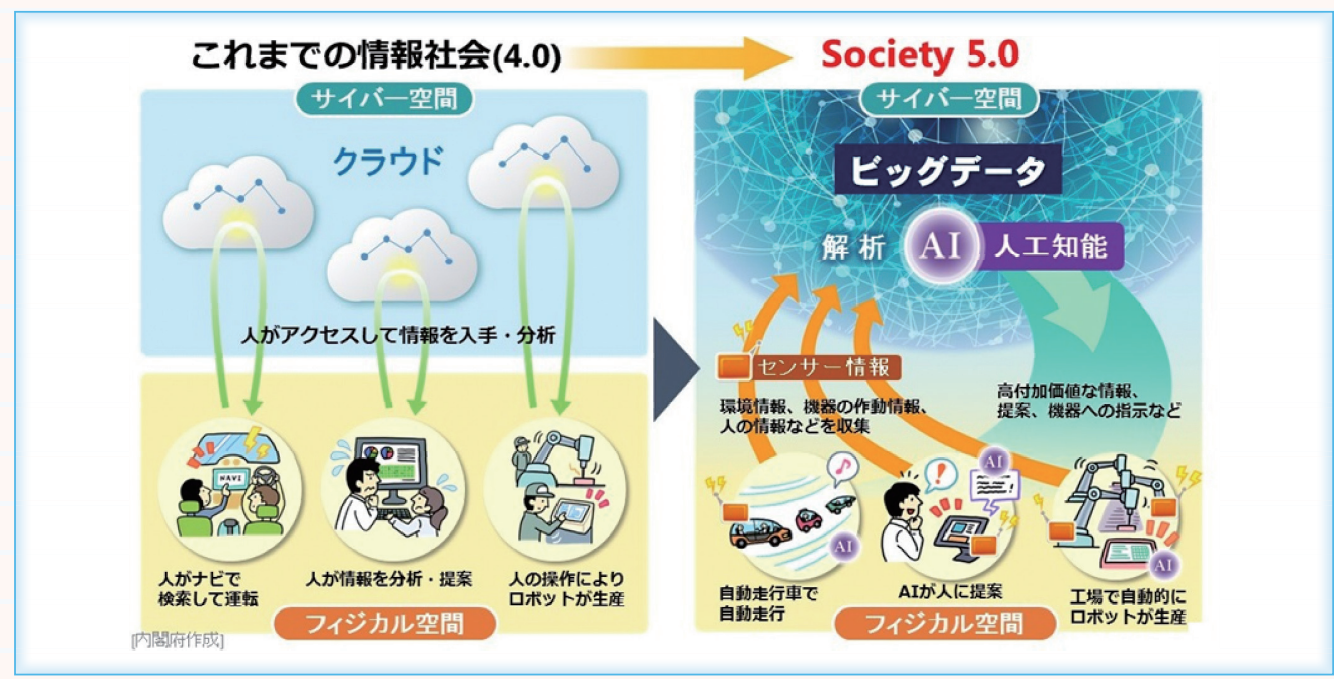

図 2 サイバー空間とフィジカル空間の高度な融合

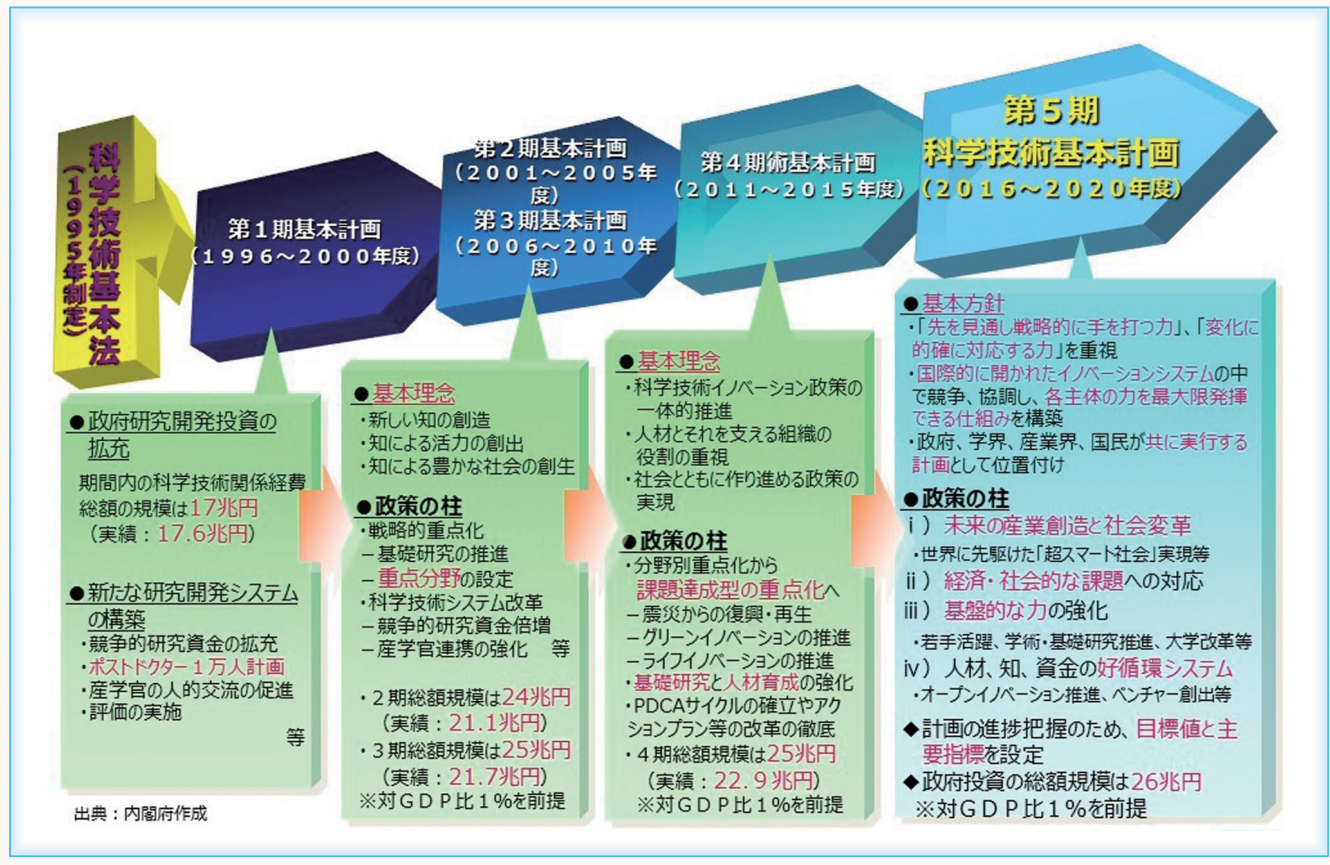

図 3 科学技術基本計画の経緯

技術・イノベーション会議（CSTI）として初めて策定 した計画である。

本基本計画は，政府，学界，産業界，国民といった幅 広い関係者が共に実行することにより，我が国を「世界 で最もイノベーションに適した国」に導くことを目的と するものである.

第 5 期科学技術基本計画の主なポイントとしては, 「Society5.0」という新たな概念を示しその実現を提唱 するとともに, 若手人材の育成・活躍促進と大学の改 革・機能強化を中心とする「科学技術イノベーションの 基盤力強化」, 企業, 大学, 公的研究機関の本格的連携と心゙ ンチャー企業の創出強化などを通じた「人材，知，資金 の好循環システム」, 官民合わせた研究開発投資を対 GDP 比 $4 \%$ 以上，政府研究開発投資について対 GDP 比 $1 \%$
（総額の規模は約 26 兆円）の確保を目指す「研究開発 投資の確保」を提言していることなどが挙げられる。

\section{3 科学技術イノベーション総合戦略 2017}

科学技術イノベーション総合戦略は，5 か年にわたる 基本計画の下，毎年の状況変化を踏まえて，年度ごとに 重点を置くべき施策を示すものである。科学技術イノ ベーション総合戦略 2017 は, 第 5 期科学技術基本計画 （2016２020 年度）の 2 年度目の総合戦略であり, 我 が国を世界で最もイノベーションに適した国に変革すべ く推進する取組についてとりまとめている.

総合戦略 2017 の主なポイントとしては，プラット ホームを支える基盤技術の強化として，特に AI 関連技 術については, 人工知能技術戦略会議策定の産業化ロー 
ドマップ等を国家戦略とし，研究開発から社会実装まで 政府一体で推進すること（3. 参照）や，CSTI の司令塔 機能の強化を図りつつ，Society 5.0 の実現に資する科 学技術予算の量的・質的拡大を目指す「予算編成プロセ ス改革」(4.の官民研究開発投資拡大プログラム 「PRISM」参照) などが提言されている。

\section{(3)人工知能技術戦略会議}

\section{1 経緯}

人工知能技術戦略会議は，2016 年 4 月 12 日に開催 された第 5 回「未来投資に向けた官民対話」において, 安倍総理による「人工知能の研究開発目標と産業化の ロードマップを本年度中に策定します。そのため，産学 官の阽智を集め，縦割りを排した『人工知能技術戦略会 議』を創設します.」との発言を受け設置された。

人工知能技術戦略会議は，我が国の政府における $\mathrm{AI}$ 研究開発の司令塔として, 総務省, 文部科学省及び経済 産業省の 3 省が所管する五つの研究開発法人（情報通 信研究機構, 理化学研究所, 科学技術振興機構, 産業技 術総合研究所及び新エネルギー・産業技術総合開発機 構）の研究開発の連携を図ることが主な目的とされた。

本会議の議長は安西祐一郎氏（日本学術振興会顧問） が務め, 各研究開発法人理事長, 経団連未来産業技術委 員会委員長, 東京大学及び大阪大学総長が構成員として 参加し, 総務省, 文部科学省及び経済産業省の 3 省が 事務局を担当することとなった。

\section{2 産業化ロードマップの策定}

人工知能技術戦略会議は，2017 年 3 月に人工知能技 術戦略を策定した。同戦略では, AI 研究開発の関係官 庁である総務省，文部科学省及び経済産業省が連携し， 我が国が有する現場の強みを踏まえ, 研究開発から社会 実装まで一貫した取組の加速していく必要性があるとの 観点から，AI とその他関連技術の融合による産業化の ロードマップを策定した。

具体的には，AI 技術の研究開発について，民間投資 を促進するための重点分野として,「生産性」,「健康, 医療・介護」「空間の移動」の 3 分野を特定し，それぞ れフェーズ 1, フェーズ 2, フェーズ 3 （フェーズ 1 と 2 の境界がおおむね 2020 年，フェーズ 2 と 3 の境界が おおむね 2025 年〜2030 年）に分けた上で，3 段階の フェーズごとに産業化の進展を整理したものである。併 せて，これらのチャレンジングな目標を実現するための 研究開発目標についてもとりまとめている. なお, 重点 分野は, 上記の 3 分野に加えて, 横断的な分野として 「情報セキュリティ」が挙げられている.

図 4，5，6に 3 分野の産業化ロードマップを示す.

\section{3 司令塔機能の強化}

「3.1 経緯」に述べたとおり，人工知能技術戦略会議 は, $\mathrm{AI}$ 研究開発を所管する 3 省による研究開発施策の 連携を主な目的として設置されたものである。しかしな がら, AI については, 今後, 研究開発に加えて社会実 装の推進の重要性が増大することが予想される。

このため，人工知能技術戦略会議においては，今後,

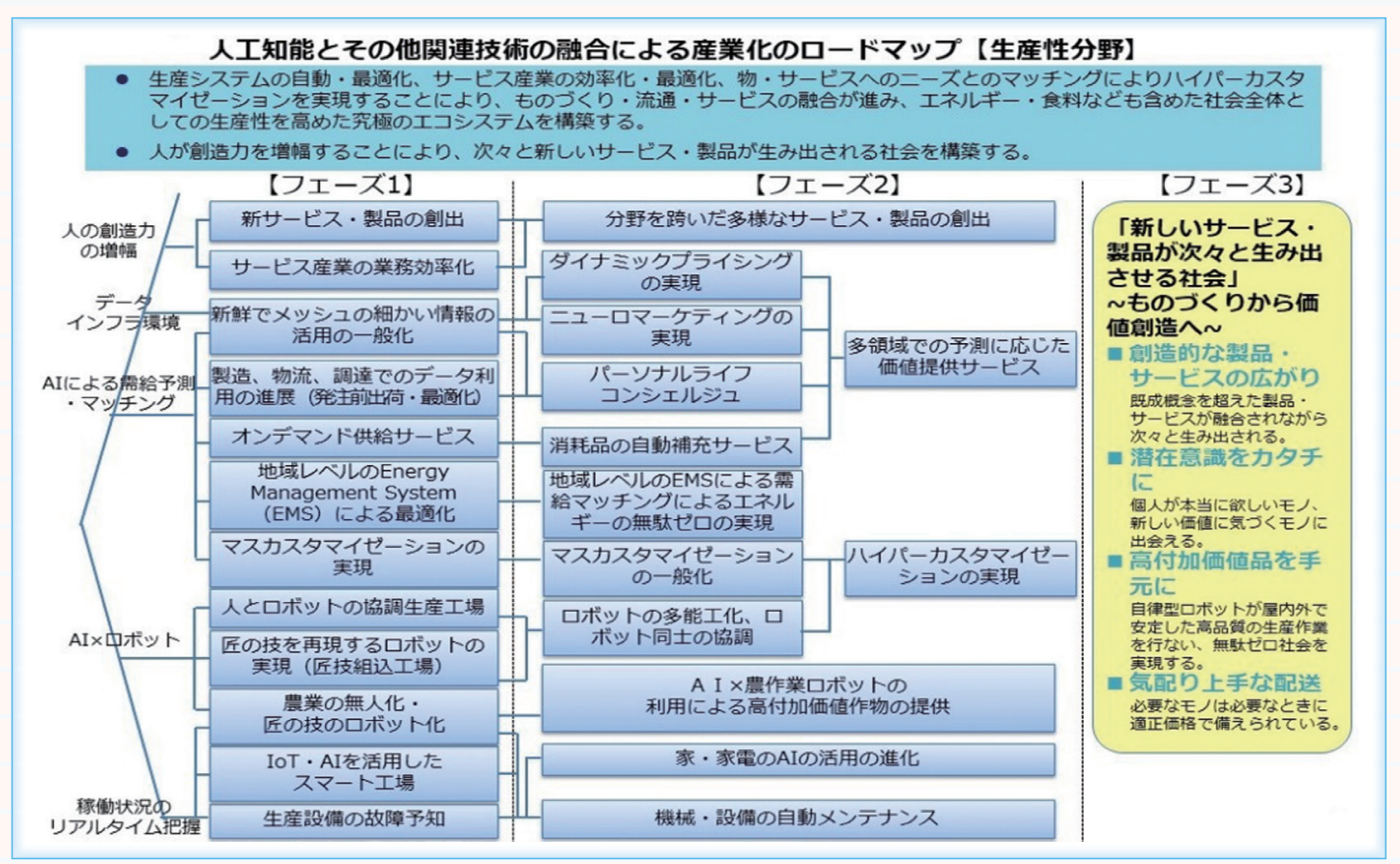

図 4 産業化ロードマップ（生産性分野） 


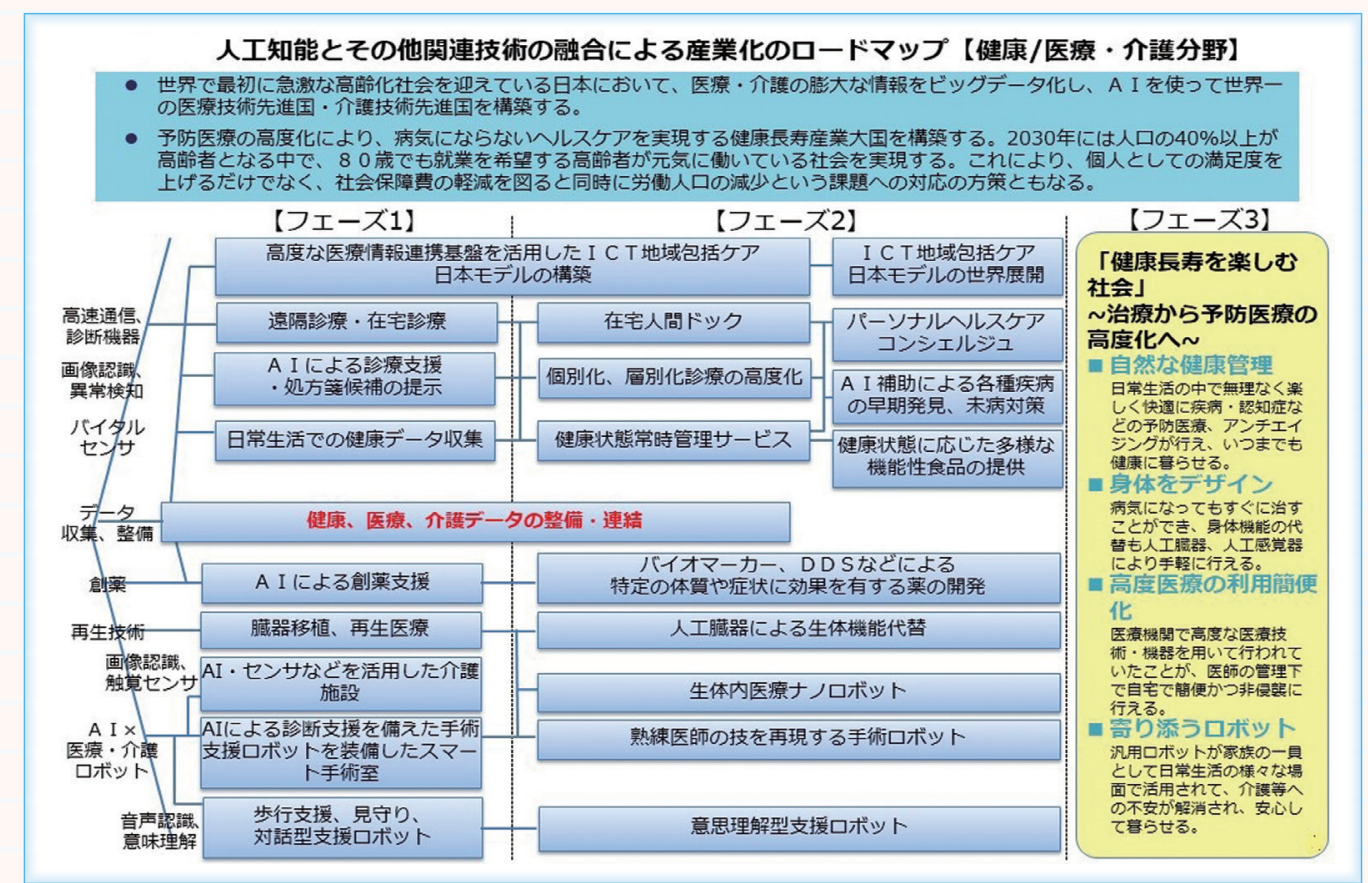

図 5 産業化ロードマップ（健康／医療・介護分野）

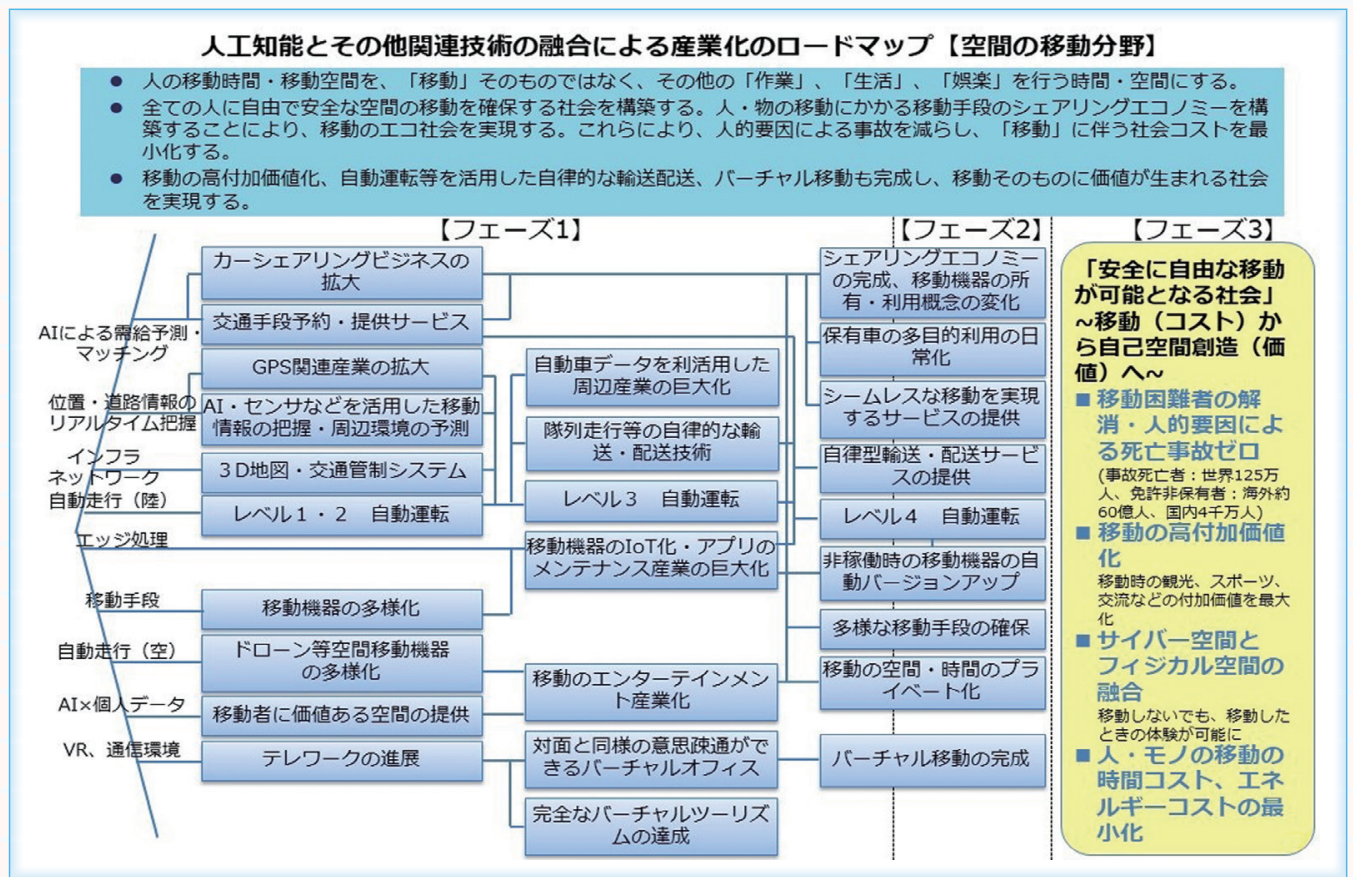

図 6 産業化ロードマップ（空間の移動分野）

従来の研究開発戦略の観点のみならず，人材育成，制 度，振興など社会実装の戦略まで含めた課題について取 り組む司令塔として機能を強化すべく，2017 年 12 月, 会議事務局として，これまでの総務省，文部科学省，経 済産業省の 3 省に加えて, $\mathrm{AI}$ の社会実装に関係する厚 生労働省，農林水産省及び国土交通省並びに政府全体の とりまとめとして内閣府が参画することを決定した（図 7)。これに併せて, 同会議構成員も，厚生労㗢省，農 林水産省及び国土交通省の関係国立研究開発法人の理事 長が新たに加わることとなった。

\section{官民研究開発投資拡大プログ ラム (PRISM)}

GDP600 兆円経済の実現に向けて，成長のエンジン である科学技術イノベーションの活性化を図るため, CSTI と経済財政諮問会議の下に設置された経済社会・ 科学技術イノベーション活性化委員会が 2016 年 12 月 にとりまとめた「科学技術イノベーション官民投資拡大 イニシアチブ」において，官民研究開発投資拡大プログ ラム (PRISM) の創設が提言された。 


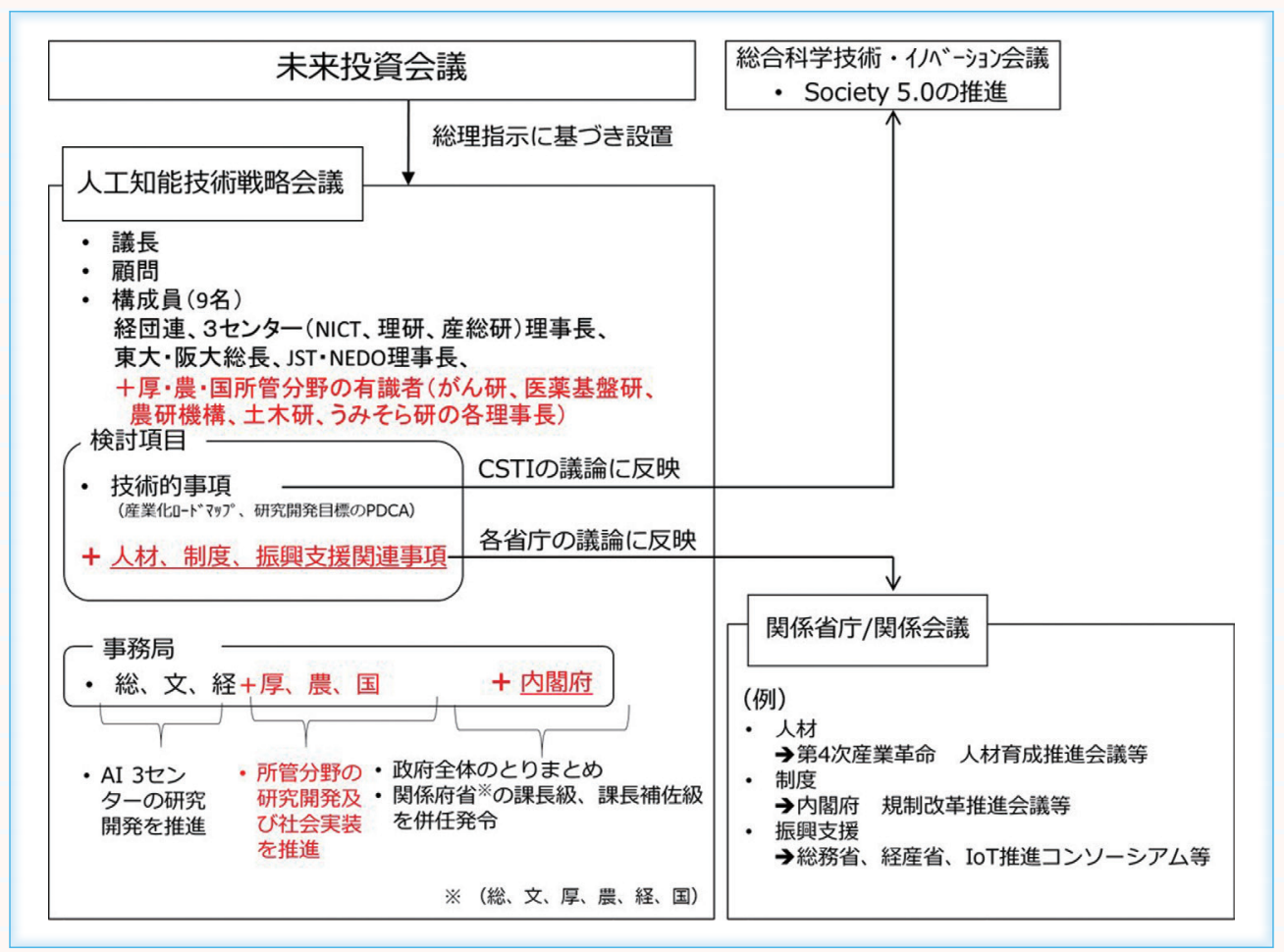

図 7 人工知能技術戦略会議 司令塔機能強化

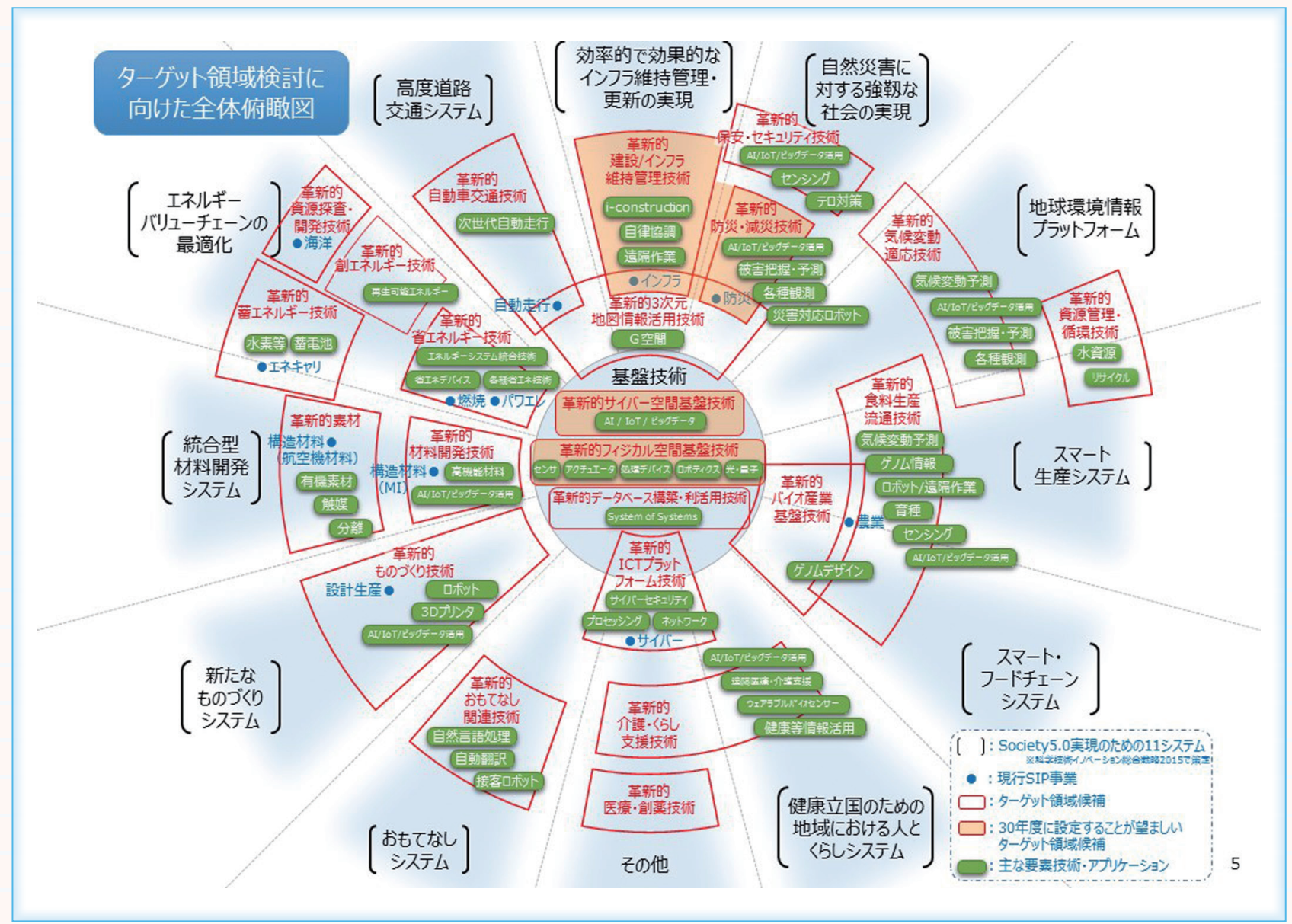

図８PRISM ターゲット領域の俯瞰図 
PRISM は，官民研究開発投資の量的・質的拡大を目 指して，2018 年度より開始されるプログラムである。 特徵としては，官民で民間投資誘発効果の高いターゲッ 卜領域を設定した上で，CSTI 及び産業界が選定した各 省の提案事業に対して推進費をアドオンすることによ り，CSTIにより各省主導の施策を民間投資誘発効果の 高い分野に誘導することを狙いとしていることが挙げら れる。

ターゲット領域については，2017 年 4 月の CSTI の 本会議において，当該領域への政府研究開発投資によ り，(1)産業界の研究開発投資が誘発されるか，(2)研究開 発成果の活用による政府支出の効率化への貢献一の二つ の視点で検討された。同会議においては，2018 年度に 設定することを前提に準備を進めるターゲット領域とし て, AI, IoT, ビッグデータから成る「革新的サイバー 空間基盤技術」のほか，「革新的フィジカル空間基盤技 術」及び「革新的建設・インフラ維持管理技術」の 3 領域が決定されるとともに，2019 年度以降に設定する ことが望ましい10のターゲット領域候補についても決 定された（図 8)。

PRISM の主な目的は, 以下の 3 点である.

(1) 民間投資誘発効果の高い研究開発領域（「ター ゲット領域」）に，各省施策を誘導すること

(2) SIP 型マネジメントを各省施策に展開すること

(3) ターゲット領域で世界に勝つための戦略を検討 し，各省施策をそれに向けて紏合すること

なお，AI， IoT，ビッグデータから成る「革新的サイ バー空間基盤技術」の領域統括は，「人工知能技術戦略 会議」議長の安西祐一郎氏が兼ねており，内閣府として は，予算の裏付けを有する PRISM と人工知能技術戦略 会議において検討される AI 戦略とを有機的に連動する ことにより，「産業化ロードマップ」の重点 3 分野に注 力しつつ, 政府の $\mathrm{AI}$ 関連政策全体をコントロールする ことを目指している.

\section{おわりに}

アベノミクスでこれまでに設定した「世界最高水準の イノベーション環境を目指す」などの目標の達成のため には，今後，これまで述べてきた具体的な取組の更なる 強化, 加速化, 拡大に向けて, 我が国のイノベーション 政策の抜本的に強化していく必要がある.

具体的には，グローバルな技術開発競争が激化しつつ ある中，我が国が強みを有する豊富な技術シーズを社会 実装に結び付けていくため，次期 SIP や PRISM による 研究開発について，社会実装を念頭に置いた上で，国際 競争に勝ち抜くことを目標とした戦略的な取組が必要と 考えられる。

また，AI を活用しながら Society5.0 を真に実現して いく上で，我が国に存在する様々な情報デー夕を連結す ることが重要であるが，我が国における情報データの収 集，蓄積とそれらの連結が必ずしも十分でないことか ら，内閣府としては，我が国に分散する情報データを効 率的に連携するための仕組みの構築について，早急に検 討を進める必要があると考えている。

内閣府においては, 今後, 人工知能技術戦略会議を我 が国の AI 戦略の司令塔として，CSTI や各省庁におけ る $\mathrm{AI}$ 関連施策を戦略的に推進することにより，我が国 における Society 5.0 の実現とそれによるイノベーショ ンの更なる創出に向けた環境整備を推進していく予定で ある。

\section{新田隆夫}

1990 慶大 $\cdot$ 理工 $\cdot$ 電気卒. 1992 同大学院修士課程了. 同年郵 政省入省. 以来，主に電波行政，放送行政などに従事．現在，内 閣府政策統括官（科学技術・イノベーション担当）付参事官（社 会システム基盤担当）として, 政府の人工知能技術戦略, Society 5.0 本格実装に向けたデータ連携基盤の検討などを担当. 